\title{
W stulecie nawiązania polsko-rumuńskich stosunków dyplomatycznych. Sympozjum naukowe w Suczawie
}

esienią 1999 r. Związek Polaków w Rumunii - organizacja polonijna
z siedzibą w Suczawie - zorganizował spotkanie kilku polskich i rumuńskich historyków poświęcone 60 rocznicy wybuchu II wojny światowej i uchodźstwa polskiego do Rumunii pt. „Druga wojna światowa na tle stosunków polsko-rumuńskich”. Towarzyszyły mu okolicznościowa wystawa fotograficzna i koncert. W roku następnym impreza zyskała nazwę Dni Polskich, a podczas naukowego spotkania wystąpiło już 21 prelegentów, poza historykami także filolodzy i etnografowie. Z roku na rok rosła ich liczba, a do historyków dołączali znawcy problematyki bukowińskiej i polonijnej, filolodzy, rumuniści z Polski i poloniści z Rumunii, etnografowie, geografowie, historycy sztuki, historycy kultury, nie tylko z Polski i Rumunii, ale także z Ukrainy czy Republiki Mołdawii. Dni Polskie stały się przedsięwzięciem dorocznym, podobnie jak ich stały element - sympozjum naukowe na temat szeroko pojętych relacji polsko-rumuńskich na przestrzeni wieków w najróżniejszych ich przejawach.

Tegoroczne 21 sympozjum w ramach Dni Polskich odbyło się 29-30 sierpnia 2019 r. Jego tytułem - „O relacjach polsko-rumuńskich na przestrzeni wieków w stulecie nawiązania stosunków dyplomatycznych”organizatorzy podkreślić chcieli znaczenie tego historycznego dla obu krajów momentu. Sympozjum charakteryzowała duża różnorodność tematyczna i rozpiętość czasowa prezentowanych zagadnień, co zresztą od lat jest celowym zamierzeniem. Referenci z Polski, Rumunii i Ukrainy zapre- 
zentowali 46 wystąpień, z czego 22 w sekcji „W kręgu historii”, 13 w sekcji „W kręgu kultury i literatury” oraz $11 \mathrm{w}$ sekcji „W kręgu problematyki bukowińskiej".

Tradycyjnie już najliczniej reprezentowaną była podzielona na chronologiczne panele sekcja „W kręgu historii”. Znalazł się w niej panel obejmujący okres XVI-XVIII w., dotyczący najdawniejszych relacji polsko-mołdawskich (moderowany przez prof. Ilonę Czamańską z Uniwersytetu im. Adama Mickiewicza w Poznaniu), oraz najliczniej zazwyczaj reprezentowany podczas suczawskich spotkań panel prezentujący intensywne relacje obustronne w okresie międzywojennym (moderowany przez prof. Waldemara Rezmera z Uniwersytetu Mikołaja Kopernika w Toruniu oraz dr. Iona Constantina z Narodowego Instytutu Badań Totalitaryzmu w Bukareszcie), z kilkoma wystąpieniami poświęconymi wydarzeniom rocznicowym: stuleciu polsko-rumuńskich stosunków dyplomatycznych czy wybuchowi II wojny światowej i uchodźstwu polskiemu do Rumunii. Panel poświęcony historii najnowszej (moderowany przez prof. Radosława Zenderowskiego z Uniwersytetu Kardynała Stefana Wyszyńskiego w Warszawie) w tym roku był wyjątkowo bogaty i poruszono w jego ramach także wiele zagadnień politologicznych.

Bardzo ciekawie zaprezentowały się także pozostałe sekcje. W ramach sekcji „W kręgu kultury i literatury”, moderowanej przez prof. Olimpię Mitric z Uniwersytetu im. Stefana Wielkiego w Suczawie i prof. Constantina Geambașu z Uniwersytetu w Bukareszcie, przedstawiono niezwykle różnorodną tematykę - od aspektów literackich i omówienia poloników czy rumuńskich śladów w polskich muzeach przez prezentację ciekawych postaci po zagadnienia dotyczące inspiracji czerpanych z kultury i realiów innego kraju. W sekcji „W kręgu problematyki bukowińskiej”, moderowanej przez prof. Helenę Krasowską z Instytutu Slawistyki PAN i prof. Eugeniusza Kłoska z Uniwersytetu Wrocławskiego, historycy, etnografowie, językoznawcy i socjolodzy zaprezentowali referaty poświęcone polskim mieszkańcom Bukowiny oraz wielokulturowości tego niezwykłego regionu.

Sympozjum zakończyło krótkie podsumowanie, które wygłosił prof. Krzysztof Nowak z Uniwersytetu Śląskiego w Katowicach. Poprowadził także prezentację wydawnictw związanych z tematyką relacji polsko-rumuńskich, które ukazały się w ostatnim roku w Polsce i Rumunii, stanowiącą od wielu już lat nierozłączny element sympozjum. Były to m.in.: zbiór wydany przez Związek Polaków w Rumunii, będący pokłosiem ostatniego sympozjum (O relacjach polsko-rumuńskich na przestrzeni wieków 
w Stulecie Odzyskania Niepodległości Polski i Wielkiego Zjednoczenia Rumunii. Despre relațiile polono-române de-a lungul timpului în anul Centenarului Îndependenței Poloniei și Marii Uniri a României); książka Polacy w rosyjskiej Besarabii w latach 1812-1918 (Poznań 2018), zaprezentowana przez prof. Ilonę Czamańską oraz autorkę - dr Annę Skowronek z Uniwersytetu im. Adama Mickiewicza w Poznaniu; Wizyty szefów państw w ramach wzajemnych stosunków Polski i Rumunii w dwudziestoleciu międzywojennym (Szczecin 2019) prof. Henryka Walczaka z Uniwersytetu Szczecińskiego; dwujęzyczny polsko-rumuński zbiór artykułów pod redakcją prof. Krzysztofa Nowaka i prof. Florina Anghela z Uniwersytetu Owidiusza w Konstancy, wydany przez Rumuński Instytut Kultury w Warszawie przy współpracy z Instytutem Polskim w Bukareszcie - Odrodzenie Polski i Zjednoczenie Rumunii. W stulecie nawiazania polsko-rumuńskich stosunków dyplomatycznych. Renașterea Poloniei și Unirea Romaniei. Despre centenarul stabilirii relațiilor diplomatice polono-române (Warszawa 2018) czy zaprezentowany przez redaktora - prof. Aleksandra Smolińskiego z Uniwersytetu Mikołaja Kopernika w Toruniu -zbiór Mało znana I wojna światowa. Studia i szkice z dziejów Wielkiej Wojny na froncie wschodnim oraz rumuńskim, na Morzu Śródziemnym i na Dalekim Wschodzie (Grajewo 2018). Niezwykle ważną publikację przedstawili także prof. Helena Krasowska z Instytutu Slawistyki PAN, dr Magdalena Pokrzyńska z Uniwersytetu Zielonogórskiego i prof. Lech Aleksy Suchomłynow z Międzynarodowej Szkoły Ukrainistyki Narodowej Akademii Nauk Ukrainy. Książka ich autorstwa, Świadectwo zanikajacego dziedzictwa. Mowa polska na Bukowinie: Rumunia - Ukraina, wydana w 2018 r. przez Instytut Slawistyki PAN, jest bowiem pierwszym całościowym studium dotyczącym mowy Polaków zamieszkujących zarówno rumuńską, jak i ukraińską Bukowinę. Podczas promocji wydawnictw zaprezentowano również Wielki stownik polsko-rumuński autorstwa Iona Robciuka oraz Constantina Geambaşu, Vasile Moga, Mariny Ilie i Cristiny Godun, wydany pod patronatem Prezydentów RP i Rumunii z okazji stulecia nawiązania polsko-rumuńskich stosunków dyplomatycznych.

Suczawskie sympozjum, odbywające się w ramach Dni Polskich, to jedyne tego rodzaju przedsięwzięcie, organizowane nieprzerwanie od ponad 20 lat, podczas którego spotyka się tak liczne grono badaczy i osób zainteresowanych tematyką relacji polsko-rumuńskich, zwłaszcza ich historycznymi aspektami. W ciągu ostatnich 20 lat podczas sympozjum wystąpiło 275 referentów, wygłoszono 659 referatów, a w dorocznych 20 publikacjach 
znalazło się do tej pory 587 artykułów z różnorodnych dziedzin. Spotkanie w Suczawie to jednak nie tylko sympozjum i będące jego rezultatem zbiory, ale także wszystko to, co dzieje się jakby na jego marginesie - wymiana myśli i doświadczeń, nawiązujące się przyjaźnie i współpraca, rodzące się w kuluarach nowe projekty, inicjatywy, publikacje. Całemu przedsięwzięciu od wielu lat przyświeca hasło „Bliżej siebie”. Związek Polaków w Rumunii jako organizator stara się stworzyć sprzyjającą atmosferę i dogodne ku temu warunki.

Elżbieta Wieruszewska-Calistru 